\title{
Contextualizing the History of the Enslaved
} Modalities of Coercion and Shifting Labor and Power Relations

\author{
Juliane Schiel \\ University of Vienna, Vienna, Austria \\ juliane.schiel@univie.ac.at \\ Christian G. De Vito \\ University of Bonn, Bonn, Germany \\ cdevito@uni-bonn.de
}

\begin{abstract}
This introduction highlights the contribution of the special issue to a radical contextualisation of the history of the enslaved. In particular, it suggests that the conditions and circumstances that foster or hamper practices of enslavement need to be studied as part of a broader set of labor relations. And it proposes that shifts in the practices of enslavement are closely related to broader transitions in power relations. This double expansion allows connecting the history of enslavement and the enslaved with broader themes in labor and social history.
\end{abstract}

\section{Keywords}

slavery - coercion - labor relations - power relations - asymmetries - longue durée transregional history - global history

This special issue is the product of a network of scholars interested in the study of labor coercion and social bondage in a diachronic and transregional perspective. Having started as a working group on "Free and Unfree Labour" in 2013, it is now running a cost Action on "Worlds of Related Coercions in Work" (wORCK), funded by the Horizon 2020 Framework Programme of the Euro-

1 https://socialhistoryportal.org/elhn/wg-coercion. 
pean Union. ${ }^{2}$ While studying the coerced "workers of the world" 3 in different time periods and world regions, the network not only calls for a change of perspective in labor history by "linking the stories of work and production with those of violence, expropriation and marginalization,"4 but it also views "labor relations as standardly diverse, coexisting, entangled, and overlapping across history" and seeks to understand the underlying modalities of coercion in historically specific social formations. ${ }^{5}$

The special issue in hand focuses on sets of labor relations involving enslaved people. It presents four case studies of specific social formations in which the status of the enslaved and the practice of enslavement underwent major modifications. Thereby, the volume features articles that trace a unique route from the Adriatic Sea region of the European middle ages to the Ming-Qing period of late imperial China, and from the French colony of Saint-Domingue in the Caribbean around 1700 to the Tahoua region of contemporary Niger in West Africa.

The first article, by Juliane Schiel, examines late medieval Ragusa (today's Dubrovnik), where unskilled migrant workers and captured people from the Slavic hinterlands were gradually absorbed by the increasing labor demand of the surrounding sea powers and the logics of a commodified maritime economy. The emerging slave trade of the Mediterranean not only produced new labels and modes of exploitation for the "maids-of-all-work" working in Ragusan households or elsewhere in Southern Europe; it also created a new discourse clearly distinguishing between the profit-making trading of human beings as unlawful and sinful practice and the legitimate use of slave labor for "personal use," officially defended by the Church as an act of charity.

The second article, by Claude Chevaleyre, is set in late imperial China, where more and more commoners started buying "adopted sons" and keeping them as slaves in order to bypass the rule of the Great Ming Code that had restricted the ownership of slaves to a small state elite. The numerous legislative reforms of the Ming and Qing dynasties sought to inhibit this practice by reconfiguring the legal status of the "hired worker." Yet, by gradually changing the notion of "service" and "servitude" connected to these hired household workers, the new

2 https://www.cost.eu/actions/CA18205/\#tabs|Name:overview.

3 Marcel van der Linden, Workers of the World: Essays Toward a Global Labor History (Leiden: Brill, 2010).

4 https://www.worck.eu.

5 Christian G. De Vito, Juliane Schiel, and Matthias van Rossum, "From Bondage to Precariousness? New Perspectives on Labor and Social History," Journal of Social History 54, no. 2 (2020): $1-19$. 
regulations ultimately turned the gradual difference between slaves and hired workers into a categorical distinction.

The third article, by Karsten Voss $\dagger$ and Klaus Weber, analyzes the period of the late 17th-century sugar revolutions, when the French Governor JeanBaptiste du Casse aimed to make Saint-Domingue a lucrative colony, economically competitive with the neighboring British island of Jamaica. Instead of continuing to rely on white indentured servants, most of whom consisted of poor people and convicts from France, du Casse encouraged investment in slaves from Africa. During the initial phase, these slaves were also used as mortgageable assets to increase the investors' credit for more land and more slaves. The treatment of slaves became worse as they became more readily available in Saint-Domingue, and their employment as the main workforce in sugar production and other sectors varied greatly, depending on the alternating logics of war and peace economies.

The final article, by Benedetta Rossi, takes us to the vast hinterlands of Niger, where slavery has remained a living institution up to today. First, France's civilizing mandate to suppress indigenous slavery clashed with the use of forced labor recruitment for the implementation of colonial projects, and limited economic means rendered the control of the Tuareg's practices of enslavement in the countryside impossible. Then, following decolonization, slavery became a taboo, leaving no traces in the post-independence archival records. Yet, fieldbased research proves the de facto continuation of a resilient institution: without political and public support, the relatively choiceless slave descendants of Tahoua opt for dependence, and precolonial hierarchies live on.

All things considered, two general observations can be made from these four case studies. First, the conditions and circumstances that foster or hamper practices of enslavement, be it as legitimate institution de jure or as living institution de facto, need to be studied as part of a broader set of labor relations. The histories of slaves are closely related to those of domestic servants and hired workers (as in the cases of the medieval Mediterranean and late imperial China), as well as to indentured servants and forced laborers (as can be seen in the colonies of the Caribbean or in French West Africa). Second, it seems that the appearance and disappearance, as well as the transformation or reappearance of practices of enslavement are essentially an issue of shifting power relations. In most cases, the (re)negotiating of these power relations is not primarily about the enslaved people. Rather, the legal and social redefinition of the most vulnerable parts of society as a whole turns out to be part of broader economic, social or political struggles. From this perspective, the articles included in this special issue are an invitation to place changes in the legal regimes and practices of enslavement in the broader context of social and 
power relations. Indeed, the shifting conditions and attributions for unskilled household workers from the Balkan hinterlands depended on the economic wars fought between the Dalmatian port cities, seeking to protect their domestic labor market, and the Mediterranean powers looking for a new cheap labor force. In late imperial China, the new categorical distinction between slaves, belonging to the legal category of "mean people," and hired laborers, whose legal status had been gradually revalued, was a side-effect of the general power struggle between the state elite and the commoners of the Ming-Qing period. The French governor's decision to opt for the massive import of African slaves, rather than for white indentured laborers, to Saint-Domingue, was the consequence of a change in strategy. If Jean-Baptiste du Casse wanted to draw economic profit from the advent of more peaceful times in Europe and invest in the large-scale production of sugar, so highly in demand in Europe, slaves were the best way to increase the colony's capital and enable quick and big investments, as they could serve as mortgageable assets of high value. In the case of Niger, practices of enslavement changed as colonial abolitionism was imposed on Tahoua's society, giving new options to enslaved persons. However, these options were limited: France's forced labor policies and the narrow range of free employment opportunities accessible to ex-slaves resulted in the latter's frequent acceptance of continuing dependence on former masters. Whereas in colonial times, enslavers and the enslaved revolted against the forced labor recruitments of the colonizers, the new tabooing of slavery from the independent government prevents political intervention and enables the lingering vitality of old practices.

This special issue therefore makes the case for a radical contextualization of the history of the enslaved. It not only links their histories to those of other coerced laborers, but it also seeks to detect the modalities of coercion of the asymmetrical power relations that were at stake. By situating and comparing specific cases from different time periods and world regions, this special issue not only contributes to the study of slavery and current debates in global labor history — it may also help to conceptualize a new social history.

\section{Works Cited}

De Vito, Christian G., Juliane Schiel, and Matthias van Rossum. "From Bondage to Precariousness? New Perspectives on Labor and Social History." Journal of Social History $54(2)(2020), 1-19$.

Linden, Marcel van der. Workers of the World: Essays Toward a Global Labor History (Leiden: Brill, 2010). 